Ключевые слова: жанр ужасов (хоррор), американистика, современная русская литература, сравнительный и жанровый анализ литературы, повествовательные стратегии, преподавание литературы ужасов.

Сведения об авторе:

Малых Вячеслав Сергеевич, канд. филол. наук, переводчик с китайского и английского языков (г. Ижевск, Россия); e-mail: viaclaf@yandex.ru.

\title{
Литература:
}

1. Хейзинга Й. Осень Средневековья. Издательство Ивана Лимбаха, 2016. 768 с.

2. Хайдеггер М. Бытие и Время. М.: Академический проект, 2015. 460 с.

3. Бердяев Н. Философия свободы. Смысл творчества. Опыт оправдания человека. М.: Русская философия, 2015. $528 \mathrm{c}$.

4. Todorov, T. The Fantastic: A Structural Approach to a Literary Genre. New York, 1973, 179 p.

5. Carroll, N. The Philosophy of Horror: Or, Paradoxes of the Heart. New York and London, 2004, $256 \mathrm{p}$.

6. Badley, L. Writing Horror and the Body: The Fiction of Stephen King, Clive Barker, and Anne Rice (Contributions to the Study of Popular Culture). Westport, Connecticut-London, 1996, 183 p.

7. Hantke, S. (Ed.) Horror. University Press of Mississippi, Delta Productions, 2002, 240 p.

8. Hantke, S. (Ed.) Horror Film: Creating and Marketing Fear. University Press of Mississippi, 2004, $261 \mathrm{p}$.

9. Hantke, S. (Ed.) American Horror Film: The Genre at the Turn of the Millennium. University Press of Mississippi, 2010, $253 \mathrm{p}$.

10. Hantke, S. (Ed.) Monsters in the Machine: Science Fiction Film and the Militarization of America after World War II. University Press of Mississippi, 2018, 246 p.

11. Radcliffe, A. "On the Supernatural in Poetry." The New Monthly Magazine and Literary Journal, vol. 16, no. 1, 1826, pp. 145-152.

12. Lovecraft, H. P. Supernatural Horror in Literature. New York, 1973, pp.11-106.

13. King, S. Danse Macabre. New York, 1981, 400 p.

14. King, S. On Writing: A Memoir of the Craft. New York, 2002, 320 p.

15. Oates, J. C., King, S., Carol, J., Ellison, H., Morrell, D. and others. On Writing Horror: A Handbook by the Horror Writers Association. New York, 2006, 272 p.

16. Hubert, K. M. Teaching and Writing Popular Fiction: Horror, Adventure, Mystery and Romance in the American Classroom. New York, 2000, 240 p.

17. Matek, L. "Teaching Horror Literature in a Multicultural Classroom." English Language Overseas Perspectives and Enquiries, no. 12(1), 2015, pp. 61-73.

18. Weiss, M. J. A Teacher's Guide to Selected Horror Short Stories of Stephen King: From the Anthologies Night Shift, Nightmares and Dreamscapes, and Skeleton Crew. New York, 1995, 20 p.

УДК 821.133.1-1:821.161.1-1(045)

\author{
Coates C. F.
}

Binghamton University, State University of New York

Binghamton, New York, U.S.A

\section{LA FONTAINE AND KRYLOV: THE ART OF NEGLIGENCE}

In the French vers libres of the seventeenth century, we expect to find, most commonly, varied sequences of long lines (alexandrines and decasyllables) and short lines (eight or fewer syllables), linked by unsystematic rhyme groups in neighboring rhyme (AABBCC...), in four-line groups (alternating rhyme, $\mathrm{ABAB}$, or enclosed rhyme $\mathrm{ABBA}$ ) or in varied groups of five or more lines on two or more rhymes. An isolated line with no answering rhyme was unknown.

Two of the great fabulists have produced one fable with a missing rhyme: La Fontaine ("La Cour du Lion") and Ivan Krylov («Купец»). Critics who have noticed the missing rhyme in "La Cour du Lion" have assumed that La Fontaine was negligent or careless. No commentator of Krylov's «Басни», so far as I can determine, has noted the missing rhyme in «Купец». Each fable 
belongs to the mid-career of the poet: "La Cour..." was published in an augmented edition of the Fables in 1678; «Купец» appeared in the «Басни» of 1830, four years after Nicholas I replaced Alexander I as Tsar.

This study will consist of a close reading of "La Cour du Lion" and «Купец». The historical context for the publication of each fable will be considered and I propose that, in each case, the line with a missing rhyme be considered as a deliberate phenomenon in the poetic discourse of the fable, rather than as an act of negligence by the fabulist.

Key words: fable, anecdote, moral, versification, rhyme, Louis XIV, Nicholas I.

About the author:

Coates, Carrol Franklin, Professor Emeritus of French, Comparative Literature, and Linguistics, retired from Binghamton University-SUNY, (Binghamton, New York, U.S.A.); e-mail: ccoates@binghamton.edu.

DOI: $10.35634 / 2500-0748-2019-11-69-77$

\section{Introduction}

In reading verse fables by La Fontaine and Krylov, it is important to keep in mind that neither was content to follow the crowd in composing "free verse" with apparently random variations of meter and rhyme. This observation has implications for understanding the fables under consideration. In a "hermeneutic reading" of the poem [Riffaterre, 1978: 5], the reader must reread the text noting not only possible double meanings, plays on words, allusions to other texts, but also aspects of versification: meter, including the vertical scheme of identical or differing line lengths and their graphic placement, rhyme quality and the vertical rhyme schemes created by groups of more than two to four lines, and other deviations from the "rules" of poetic composition, including an unexpected absence of rhyme. Along these lines, Chervenka writes of «параязыковые явления в узком смысле слова: голосовые и иные (визуальные) элементы, которые к стихотворению и впечатлению от него добавляет деятельность чтеца и - в рамках наиболее обычного способа восприятия поэзии, чтения про себя - графическая организация текста» [Червенка, 2011: 147]; "paralinguistic phenomena in the narrow sense of the word: vocal and other (visual) elements that for versification and the impression [of the word] yield the reality of the recitation and within the bounds of the most ordinary method of - perception of poetry, reading in its own right - the graphic organization of the text." In short, the visual organization of the printed text, lines and the graphic placement of lines, is not directly linked to the syntactic and narrative qualities of a text.

According to A. Gaillard, "la critique de la Fable antique et païenne menée par les Modernes était profonde: puisqu'il n'était plus question d'établir des correspondances avec une Vérité (notamment chrétienne), le fabuleux païen se trouvait comme évidé..." [Gaillard, 1996: 118]; "criticism of the ancient and pagan Fable, carried out by the Moderns was profound: since it was no longer a matter of establishing correspondences with a Truth (specifically Christian), the pagan fabulous became as if hollow... ." The Fable was set, by all logic, in a horizontal modern time, that is, in a historical rather than a mythical space. La Fontaine's fables belong on the side of the Moderns, in that great quarrel between "les Anciens et les Modernes"; "the Ancients and the Moderns."

\section{La Fontaine's "La Cour du Lion"}

Among 241 numbered fables, "La Cour du Lion" stands out as Jean de La Fontaine's only fable with a missing rhyme. La Fontaine's text was published in a new edition of "The Fables" in 1678, and with modernized orthography in Collinet's excellent edition [Collinet, 1991]. Following is La Fontaine's text in French and English (translated by the author of the article):

\section{LA COUR DU LION}

Sa Majesté Lionne un jour voulut connaître

De quelles nations le Ciel l'avait fait maître.

Il manda donc par Députés

Ses Vassaux de toute nature,

\section{LION'S COURT}

His Lionic Majesty one day wanted to learn Of what nations Heaven had made him master.

So he sent forth as deputies

His vassals of all species, 


\begin{tabular}{|c|c|}
\hline $\begin{array}{l}\text { Envoyant de tous les côtés } \\
\text { ne circulaire écriture, } \\
\text { vec son sceau. L'écrit portait } \\
\text { u'un mois durant le Roi tiendrait } \\
\text { our plénière, dont l'ouverture } \\
0 \text { Devait être un fort grand festin, } \\
\text { uivi des tours de Fagotin. } \\
\text { ar ce trait de magnificence } \\
\text { e Prince à ses sujets étalait sa puissance. } \\
\text { n son Louvre il les invita. } \\
5 \text { Quel Louvre! un vrai charnier, dont l'odeur se } \\
\text { orta } \\
\text { 'abord au nez des gens. } \\
\text { 'Ours boucha sa narine: } \\
\text { se fût bien passé de faire cette mine, } \\
\text { a grimace déplut. Le Monarque irrité } \\
\text { 'envoya chez Pluton faire le dégoûté. } \\
0 \text { Le Singe approuva fort cette sévérité; } \\
\text { t flatteur excessif il loua la colère } \\
\text { t la griffe du Prince, et l'antre, et cette odeur: } \\
\text { n'était ambre, il n'était fleur, } \\
\text { ui ne fût ail au prix. Sa sotte flatterie } \\
5 \text { Eut un mauvais succès, et fut encor punie. } \\
\text { e Monseigneur du Lion-là } \\
\text { ut parent de Caligula. } \\
\text { e Renard étant proche: } \\
\text { r çà, lui dit le Sire, } \\
\text { ue sens-tu? dis-le moi: parle sans déguiser. } \\
0 \text { L'autre aussitôt de s'excuser, } \\
\text { lléguant un grand rhume: il ne pouvait que dire } \\
\text { ans odorat; bref, il s'en tire. } \\
\text { e soyez à la Cour, si vous voulez y plaire, } \\
5 \text { Ni fade adulateur, ni parleur trop sincère; } \\
\text { t tâchez quelquefois de répondre en } \\
\text { ormand. } \\
\text { a Fontaine, Fables, VII, vi.) }\end{array}$ & $\begin{array}{l}\text { A circular writ } \\
\text { With his seal. The text said } \\
\text { That during one month the King would hold } \\
\text { Plenary Court, of which the inauguration } \\
10 \text { Was to be an extraordinary festival, } \\
\text { Followed by the acrobatics of Fagotin. } \\
\text { Through this gesture of munificence } \\
\text { The Prince displayed to his subjects his power. } \\
\text { To his Louvre he invited them. } \\
15 \text { What a Louvre! a real charnel, from which the } \\
\text { odor struck } \\
\text { At once people's noses. Bear pinched his nostrils: } \\
\text { He should have avoided making that face. } \\
\text { His grimace displeased. The Monarch, irritated, } \\
\text { Sent him to Pluto's realm to make his face. } \\
20 \text { Monkey approved of this severity, } \\
\text { And, excessive flatterer, he praised the rage } \\
\text { And the claws of the Prince, and the lair, and that } \\
\text { odor: } \\
\text { There was no amber nor flower, } \\
\text { That was not, in comparison, garlic. } \\
\text { His foolish flattery } \\
25 \text { Brought poor success, and was also punished. } \\
\text { That Monseigneur Lion } \\
\text { Was related to Caligula. } \\
\text { Fox, was standing nearby: Well, said to him the } \\
\text { Sire, } \\
\text { What do you smell? Tell me. Speak without } \\
\text { pretense. } \\
30 \text { The former immediately excused himself, } \\
\text { Stating he had a bad cold: he could only speak } \\
\text { Without smelling: in short, he escaped. } \\
\text { May this serve you as a lesson, } \\
\text { At Court, if you want to please, be } \\
35 \text { Neither a pale adulator nor too sincere a } \\
\text { speaker; } \\
\text { And try often to speak Norman. }\end{array}$ \\
\hline
\end{tabular}

A number of scholars have commented on the missing rhyme for "colère" (1. 21), "anger." In an edition of selected fables, Pierre Coste moved "le dégoûté" from line 19, leaving "faire" to rhyme with "colère" [Coste, 1778: 78]:

Sa grimace déplut. Le monarque irrité

L'envoya chez Pluton faire

20 Le dégoûté.

Le Singe approuva fort cette sévérité;

Et, flatteur excessif, il loua la colère,

Et la griffe du Prince, et l'antre, et cette odeur....

His grimace displeased. The Monarch, irritated,

Sent him to Pluto's realm to make

His face.

Monkey heartily approved of this severity;

And, excessive flatterer, he praised the rage

And the claws of the Prince, and the lair, and that odor... .

Some seventy years later, Charles Nodier commented that La Fontaine's line 
21 ("Et flatteur excessif il loua la colère") " n'a point de rime, et c'est une grande négligence de La Fontaine" [Nodier, 1818: vol. 2, 25-26]; "[line 21] has no rhyme, and this is great negligence by La Fontaine." Toward the end of the nineteenth century, Étienne Souriau wrote of La Fontaine's "distraction": "La rime semble avoir occupé un rang si secondaire dans ses préoccupations poétiques qu'il lui est arrivé une distraction unique: il a oublié une fois la seconde rime [...] et a laissé imprimer le passage fautif dans toutes les éditions qu'il a pu corriger" [Souriau, 1893: 212]; "Rhyme seems to have held such a secondary rank that, in his poetic preoccupations, a unique absentmindedness came over him: for once, he forgot the second rhyme [...] and the erroneous passage has been printed in all the editions he might have corrected... ." Skipping other similar mentions, I conclude this selective list of negative suppositions with the relatively recent observation of É. Évrard, who finds that the missing echo "est vraiment trop isolé pour qu'on puisse y voir autre chose qu'une distraction ou un accident" [Évrard, 2005: 299, n. 1]; "is really too isolated for us to see anything other than absentmindedness or an accident...."

By narrative structuration, "La Cour du Lion" falls into three unequal segments. In an introductory section (11. 1-14), the narrator states King Lion's desire to summon all his subjects to a plenary session to the Louvre and offers details of the festivities. The second section (11. 15-32) relates the reactions of Bear, Monkey, and Fox. The final section (11. 33-36) is the moral of the story.

The first section opens with a couplet of alexandrines - a formal, classical statement of His Lionic Majesty's will. The enticing text of the "lettre circulaire," in contrast, speaks of a great feast followed by performances of the famous monkey, Fagotin. Both the Louvre and Fagotin are allusions to historical reality in the era of Louis XIV. The circular flows in ostensibly light-hearted octosyllabic lines, with the exception of one alexandrine (1. 13), which closes the details of the festivities: "Le prince à ses sujets étalait sa puissance."

The second section begins in alexandrines once more (11. 15-22). The animals accept the King's invitation, but the stench of a charnel strikes the nose of everybody who enters. Bear puts a paw to his nose and is rewarded with execution by the angry King. Monkey reacts with an exaggerated expression of approval of the King's severity and praise of the aroma, which once more displeases the King and is also punished by execution. When the King invites Fox to give his opinion frankly, the latter escapes regal wrath by pretending to have a cold that prevents him from smelling anything.

Beginning with a line in free indirect discourse (Monkey's own words in the imperfect tense with no first-person pronoun), the second section alternates between alexandrines and octosyllabic lines, creating a metrical dance between classical and narrative style.

The opening line of the moral, "Ceci vous sert d'enseignement" (1. 33), "May this serve you as a lesson," is a dry, unadorned invitation to pay attention to the three concluding alexandrines in which the narrator states that, at Court, one should not flatter insipidly nor be too frank, but should rather speak Norman - that is, speak little and express no opinions.

At least three specific details of the fable merit special attention. In the sequence of animal courtiers coming into this Louvre, the reactions of Bear and Monkey displease the King and incur an immediate condemnation. The case of Bear's frankness is clear: it is dangerous to express a frank opinion before the King.

The reason for Monkey's fate is less clear. Does his blatant flattery offend the King? It was not improper to flatter Louis XIV nor, we suppose, King Lion. The prevalent behavior at the Court of Louis XIV was that of the "honnête homme," a gentleman properly schooled in acting and speaking with "la mesure," moderation. This involved training in swordsmanship, in proper behavior at court affairs, including the mode of courtly dance and the art of speaking in clear but gracious tones and diction, including the ability to turn out a graceful and flattering poem for a lady. P. Hourcade speaks of Louis XIV's love of dance: “Comme son père Louis XIII, le Roi [Louis XIV] a appris très tôt la danse, y excellait et s'y complaisait. Une politique bien entendue requérait de bien mettre en valeur la bonne santé du monarque, son adresse, sa gràce, sa magnificence" [Hourcade, 2005: 152]; "Like his father, Louis XIII, the King learned dancing quite early, excelled 
in it, and enjoyed it. A well-known custom required giving notice of the good health of the Monarch, his dexterity, his charm, his splendor." No courtier would have dared create the illusion of trying to compete with the King in any manner whatsoever.

Critics have failed to notice that a missing echo for "colère" occurs (improperly) twelve lines later, in the middle of the moral:

Ne soyez à la Cour, si vous voulez y plaire,

Ni fade adulateur, ni parleur trop sincère... (11. 34-35).

The rhyme of "plaire" and "sincère" with "colère" would have made a second group of tripled rhymes, but the twelve-line separation of the latter rhyme pair has kept them from being seen as deliberate echoes of Monkey's expression, "colère." The irony of this culminating "mistake" is that the narrator's reference to the unhappy fate of both Bear and Monkey constitutes a distant, technically "non-poetic" echo. This improper distant echo serves as a technical (poetic) reinforcement by the narrator of the catatonic quality of Monkey's courtly speech.

The word "Louvre" clearly constitutes a syllepsis in that it represents two unrelated entities. It is useful to refer to L. Pushina's statement that «силлепс выступает в качестве смыслового, стилистического узла...» [Пушина, 2012: 140]; "a syllepsis stands out by its quality as a semantic, stylistic, and syntactical knot... ." in the fable, the "Louvre" is the "lair" of King Lion, but the allusion to Louis XIV's residence is unavoidable.

Although the modern Louvre, the museum in Paris, was originally a royal residence, I would suggest that La Fontaine was transparently alluding also to Versailles. On 17 August 1661, Nicolas Fouquet, Superintendant of Finances, invited Louis XIV to a sumptuous evening at his newly revamped château, Vaux-le-Vicomte. Louis Le Vau (architect), André Le Nôtre (landscape architect), and Charles Le Brun (painter) were famous collaborators at Vaux [Petitfils, 2001: 77].

It is not surprising that Louis XIV was so angered by Fouquet's display of wealth that he ended up (with insidious pressure from his other financial adviser Jean-Baptiste Colbert) having Fouquet arrested. It is likely that this provocation played a role in the development of Louis's project for making of Versailles an awe-inspiring royal palace. The inaugural event, on 7-9 May 1664, was an elaborate feast, "Les Plaisirs de l'Île enchantée" (Pleasures of the Enchanted Island [Levantal, 2009: vol. I, 232]. This was the first in a decade of great entertainments "orientés vers le merveilleux visuel, la transposition féerique des jardins et des résidences royales" [Choné, 2005: 587]; "oriented toward visual marvels, the magical transformation of royal residences." The last lines of King Lion's circular inviting his courtiers to the Louvre unambiguously reflect Louis's plans for the spectacular events at Versailles.

In his chapter on "La Cour affublée," P. Dandrey examines the last two thirds of La Fontaine's "La Cour du Lion," stating that the fabulist pointed to the cruel realities of Louis XIV's Louvre (he does not mention the possible allusion to Versailles) during his reign under the guise of an "allégorie animalière," animal allegory [Dandrey, 2009: 212]. While I am confident that Dandrey cannot have missed the lack of a rhyme for "colère," he apparently does not consider the missing rhyme of interest. Louis XIV's expectation to be obeyed, respected, entertained was as absolute as that of King Lion, with the exception that Louis XIV exiled rather than executing courtiers, such as Nicolas Fouquet, that he disliked.

\section{Krylov's «Купец»}

Ivan Andreevich Krylov’s fable, «Купец», “The Merchant” (VIII, xi; [Могилианский, 1956: 228]) is the only fable with a missing rhyme among 190 pieces in the final collective edition of the Басни. There is no overt thematic link between these two "faulty" fables of La Fontaine and Krylov. Scholars have particularly noted the humor of Andrei's discovery that his Uncle's triumph in selling a worthless piece of Polish cloth as a fine English fabric is illusory: the сотняжка (оnehundred ruble note) he accepted is counterfeit. Following is Krylov's text in Russian and English (translated by the author of the article): 


\begin{tabular}{|c|c|}
\hline $\begin{array}{c}\text { КУПЕЦ } \\
\text { «Поди-ка, брат Андрей! } \\
\text { Куда ты там запал? Поди сюда скорей, } \\
\text { Да подивуйся дяде! } \\
\text { Торгуй по-моему, так будешь не в накладе». } \\
5 \text { Так в лавке говорил племяннику Купец. } \\
\text { «Ты знаешь польского сукна конец, } \\
\text { Который у меня так долго залежался, } \\
\text { Затем, что он и стар, и подмочен, и гнил: } \\
\text { Ведь это я сукно за английское сбыл! } \\
10 \text { Вот, видишь, сей лишь час взял за него } \\
\text { сотняжку: } \\
\text { Бог олушка послал».- } \\
\text { «Все это, дядя, так», племянник отвечал: } \\
\text { «Да в олухи-то, я не знаю, кто попал: } \\
\text { Вглядись-ко: ты ведь взял фальшивую } \\
\text { бумажку». } \\
15 \text { Обманут! Обманул Купец: } \\
\text { в том дива нет; } \\
\text { Но если кто на свет } \\
\text { Повыше лавок взглянет, - } \\
\text { Увидит, что и там на ту же стать идет; } \\
\text { Почти у всех во всем один расчет: } \\
20 \text { Кого кто лучше проведет, } \\
\text { И кто кого хитрей обманет. } \\
\text { (Басни, VІІІ, хі) }\end{array}$ & $\begin{array}{l}\text { THE MERCHANT } \\
\text { "Get over here, brother Andrey! } \\
\text { Where did you go? Come here, quickly, } \\
\text { And admire your uncle! } \\
\text { Trade like me and you will not be in need." } \\
\text { 5 So spoke the Merchant to his nephew in the shop. } \\
\text { "You know that piece of Polish cloth, } \\
\text { That has been lying around here so long, } \\
\text { Because it was old, damp, and rotten: } \\
\text { Well, I sold it off as English cloth! } \\
10 \text { Look here, I took this hundred-ruble note } \\
\text { for it: } \\
\text { God sent me a great oaf."- } \\
\text { "That, uncle, may be true," answered his nephew: } \\
\text { "But, as for oafs, I don't know who got caught: } \\
\text { Just look: in fact you got a counterfeit bill." } \\
\text { 15 They cheat! The Merchant cheated: } \\
\text { no wonder there! } \\
\text { But if anyone in the world } \\
\text { Looks above the shops, } \\
\text { It will be clear that the same thing happens; } \\
\text { Almost everyone uses one calculation : } \\
20 \text { Who can mislead others better, } \\
\text { Who can cheat others more cleverly. } \\
\text { [As with La Fontaine's "La Cour...," this English } \\
\text { version strives to follow closely the Russian, not to } \\
\text { recreate Krylov's style or form.] }\end{array}$ \\
\hline
\end{tabular}

«Купец» is typographically divided into two sections: the anecdote, which consists of the conversation between the Merchant and his nephew Andrei (1l. 1-14), and a relatively long moral (11. 15-21). The merchant's short-lived delight in pawning off the worthless cloth as a fine English fabric for an exorbitant price is shattered by Andrei. In the moral, the narrator expresses no surprise that merchants cheat, but he counters that, in looking up the social ladder beyond merchant culture, almost everyone cheats, competing with one another in cheating more cleverly.

Among notable commentators, Vinogradov quoted the anecdote (11. 1-11), stressing that the speech contains typical expressions of a cloth merchant such as a «сотняжка» [Виноградов, 1990: 160]. Serman cited the same passage, noting in particular that Krylov has the Merchant reveal his "successful" sale mostly in his own words, with little narrative intervention. Serman concludes that, in contrast to Gogol or Ostrovskii, Krylov ends his story «в авторском итоговом высказывании...» [Серман, 1975: 269]; "with concluding authorial discourse." Neither Vinogradov nor Serman notices the missing rhyme for «залежался» [1. 7].

As in the case of La Fontaine, I believe that Krylov is far too knowledgeable and too careful in his poetic discourse to have left a final word without an answering rhyme. The first eleven lines of «Купец» are the words of the Merchant, with the sole exception of line 5, a case of narratorial verbum dicendi (reported speech): "So spoke the Merchant...." In fact, the Merchant is so delighted at having fooled the customer that he neglects a rhyme in his triumphant statement to Andrei. His acceptance of a counterfeit bill is paralleled by the slip in his poetic discourse, the absence of a rhyme for «залежался», "was lying around." In the excitement of presenting their knowledgeable interpretations of fables or poems, scholars, like the Merchant, may sometimes overlook important details.

The moral's invitation to look beyond the Merchant's cheating to the behavior of everyone "above" him would seem to be more directly aimed at the corruption of officialdom at all 
intermediate levels between the people and the Tsar. Unlike the story in La Fontaine's "La Cour du Lion," where the sylleptic allusion to a historical royal residence is inescapable, there is no clear evidence of any allusion to Nicholas I himself in «Купец». "The emperor's sense of duty and his straightforward religious convictions were closely connected to the general sincerity and honesty of his character" [Riasanovsky, 1959: 16]. Nikolay I was likely more concerned with establishment of his own regime and the troubled international situation between Russia, the Greeks, and the Ottomans. Excepting Nicholas I himself, the reference to cheating by everyone, from merchants up the social hierarchy toward the Tsar, is an implicit indictment of the society.

\section{Conclusion}

Without documentation of any sort, it seems quite possible that Krylov read La Fontaine's Fables with an exceptional perception of the full range of poetic discourse, meter, rhythm, and rhyme along with anecdote and narrative commentary. Krylov may well have noted the missing rhyme in "La Cour du Lion" and understood the contextual justification for the missing rhyme.

If either La Fontaine or Krylov had published other fables with a missing line, critics might have been quick to consider the possibility of a deliberate, even meaningful poetic gesture. One example in a sizeable collection of fables, however, left open the alternative that the fabulist overlooked the "mistake." It should be considered that in each case, the lack of a rhyme for one line was quite possibly a conscious decision, part of the poetic strategy of a poet seeking to invite unsuspecting readers into imitating the inattentive character of the fable - La Fontaine's Monkey, Krylov's Merchant - into committing (or failing to notice) a "careless" poetic mistake.

Along with the phenomenon of the missing rhyme in both fables, there is the possibly less obvious parallel between the historical moment of composition of each fable. When "La Cour du Lion" was written (some time before publication in 1678), Louis XIV was the recognized sole authority of an absolute monarchy. Expressions of opinion were to be carefully controlled, even avoided, if one expected to survive in proximity to the Monarch. That situation, apart from linguistic and other cultural differences, was roughly similar in Tsarist Russia under Nicholas I. «Купец» (composed before 1 November 1828 [Mogilianskii, 1956: 590]), appeared in 1830 under roughly parallel circumstances, under a new absolute Tsar, Nicolas I, who was still in the process of exercising absolute power. Although there is no transparent allusion to the Tsar, the narrative "moral" makes clear the allusion to widespread cheating by everyone from the shops upward. It would seem that Nicholas I was not a close reader of literature, especially of the low genre of fables.

\section{References:}

1. Riffaterre, M. Semiotics of Poetry. Bloomington, Indiana, 1978.

2. Chervenka, M. Meaning and Verse. Works on the Theory of Poetry. Moscow, 2011, $463 \mathrm{p}$.

3. Gaillard, A. Fables, Mythes, Contes. L'esthétique de la Fable et du Fabuleux (1660-1724). Paris, 1996.

4. Collinet, J. P. , ed. La Fontaine, Oeuvres Complètes. Fables, Contes et Nouvelles. Paris, 1991.

5. Coste, P., (Ed.) Fables de La Fontaine. Leiden, vol. 2, 1778.

6. Nodier, C., (Ed.) Fables de La Fontaine. 2 vols. Paris, 1818.

7. Souriau, É. L'Évolution du Vers Français au Dix-Septième Siècle. Paris, 1893.

8. Évrard, É. Rime et récit dans les Fables de La Fontaine. Essai statistique. Poétique de la Rime. Paris, 2005, pp. 297-312.

9. Hourcade, P. B. Bluche, F. (Eds.) Dictionnaire du Grand Siècle, Nouvelle Edition Revue et Corrigée. Paris, 2005, pp. 152-154.

10. Pushina, L. A. "Sylleptical Usage of Vocabulary in La Fontaine's and I. A. Krylov's Fables." Vestnik of the Udmurt State University, N 2, 2012, pp. 135-141.

11. Petitfils, J. C. La chute de l'Écureuil. Louis XIV. L'ordre et la gloire. Paris, 2001, pp. 76-78.

12. Levantal, C. Louis XIV. Chronographie d'un règne. Paris, 2009.

13. Choné, P. F. Bluche, F. Dictionnaire du Grand Siècle. Nouvelle Edition Revue et Corrigée. Paris, 2005, pp. 586-588. 
14. Dandrey, P. Quand Versailles Etait Conté. La Cour de Louis XIV par les Ecrivains de son Temps. Paris, 2009.

15. Krylov, I. A. Fables. Moscow, Leningrad, 1956, 635 p.

16. Vinogradov V. V. "Language and Style of Krylov's Fables." The Language and Style of Russian Writers from Karamzin to Gogol. Moscow, 1990, 390 p.

17. Serman, I. Z. "Krylov the Fabulist." Ivan Andreevich Krylov. Problems of Creative Work. Leningrad, $1975,280 \mathrm{p}$.

18. Riasanovsky, N. Nicholas I and Official Nationality in Russia, 1825-1855. Berkeley, 1959.

19. See reference 15 .

DOI: $10.35634 / 2500-0748-2019-11-69-77$

Коутс К. Ф.

Бингемтонский университет, Государственньій университет Нью-Йорка, Бингемтон, Нью-Йорк, США

\section{ЛАФОНТЕН И КРЫЛОВ: ИСКУССТВО НЕБРЕЖНОСТИ}

Во французских vers libres семнадцатого века содержатся, как правило, различные комбинации длинных строк (двенадцатисложный и десятисложный стих) и коротких строк (восемь или меньше слогов), произвольно объединяемых в сочетания смежных рифм (ААББВВ...), а также в группы из четырех строк (с перекрестной рифмовкой по типу АБАБ или опоясывающей рифмовкой по типу АББА) или в различные группы по пять или более строк, связанных двумя или более рифмами. Холостой стих - строка, оставшаяся без ответной рифмы, - не встречается.

Тем не менее, в творчестве двух великих баснописцев имеется по одной басне с холостым стихом: у Лафонтена (“La Cour du Lion”) и И. А.Крылова («Купец»). Критики, которые заметили пропущенную рифму в “La Cour du Lion”, предположили, что Лафонтен допустил этот случай по невнимательности. Ни один комментатор басен Крылова, насколько нам известно, не заметил холостого стиха в «Купце». Каждая басня относится к зрелому этапу творчества обоих поэтов: “La Cour ...” была опубликована в дополненном издании Fables в 1678 г.; «Купец» появился в «Баснях» 1830 г., через четыре года после того, как Николай I сменил Александра I на троне.

В настоящем исследовании уделяется внимание басням "La Cour du Lion" и «Купец». Привлекается исторический контекст публикации каждой басни, а также высказывается предположение, что в обоих случаях холостой стих был включен авторами в поэтический дискурс басни намеренно, он не является проявлением небрежности со стороны баснописца.

Ключевые слова: басня, сюжетная композиция, мораль, стихосложение, рифма, Людовик XIV, Николай I.

Сведения об авторе:

Коутс Керрол Франклин, почетный профессор Бингемтонского университета, кафедра французского языка, сравнительного литературоведения и лингвистики,( Бингемтон, Нью-Йорк, США); е-mail: ccoates@binghamton.edu.

\section{Литература:}

1. Riffaterre, M. Semiotics of Poetry. Bloomington, Indiana, 1978.

2. Червенка М. Смысл и стих. Труды по поэтике. М.: Языки славянской культуры, 2011, 463 с.

3. Gaillard, A. Fables, Mythes, Contes. L'esthétique de la Fable et du Fabuleux (1660-1724). Paris, 1996.

4. Collinet, J. P. (Ed.) La Fontaine, Oeuvres Complètes.. Fables, Contes et Nouvelles. Paris, 1991.

5. Coste, P. (Ed.) Fables de La Fontaine. Leiden, vol. 2, 1778.

6. Nodier, C. (Ed.) Fables de La Fontaine. 2 vols. Paris, 1818.

\footnotetext{
${ }^{1}$ Редколлегия журнала выражает благодарность Малых Вячеславу Сергеевичу, канд. филол. наук, за перевод аннотации к статье на русский язык, также за перевод источников, указанных на русском языке, на английский.
} 
7. Souriau, É. L'Évolution du Vers Français au Dix-Septième Siècle. Paris, 1893.

8. Évrard, É. Rime et récit dans les Fables de La Fontaine. Essai statistique. Poétique de la Rime. Paris, 2005, pp. 297-312.

9. Hourcade, P., Bluche, F. Ballet. Dictionnaire du Grand Siècle, Nouvelle Edition Revue et Corrigée. Paris, 2005, pp. 152-154.

10. Пушина Л. А. Силлептическое употребление лексики в баснях Ж. Лафонтена и И. А. Крылова // Вестник Удмуртского университета, 2012. N 2. C. 135-141.

11. Petitfils, J. C. La chute de l'Écureuil. Louis XIV. L'ordre et la gloire. Paris, 2001, pp. 76-78.

12. Levantal, C. Louis XIV. Chronographie d'un règne. Paris, 2009.

13. Choné, P. F., Bluche, F. Dictionnaire du Grand Siècle. Nouvelle Edition Revue et Corrigée. Paris, 2005, pp. 586-588.

14. Dandrey, P. Quand Versailles Etait Conté. La Cour de Louis XIV par les Ecrivains de son Temps. Paris, 2009.

15. Крылов И. А. Басни. Л.: Изд-во АН СССР, 1956, 635 с.

16. Виноградов В. В. Язык и стиль басен Крылова. Язык и стиль русских писателей от Карамзина до Гоголя. М.: Наука, 1990, 390 с.

17. Серман И. 3. Крылов - баснописец // Иван Андреевич Крылов. Проблемы творчества. Л.: Наука, 1975, 280 с.

18. Riasanovsky, N. Nicholas I and Official Nationality in Russia, 1825-1855. Berkeley, 1959.

19. See reference 15. 